\title{
DIMENSI-DIMENSI KONTEKSTUAL DI DALAM PENULISAN BUKU TEKS PELAJARAN BAHASA INDONESIA
}

\author{
oleh Maman Suryaman \\ FBS Universitas Negeri Yogyakarta
}

\begin{abstract}
This article is about a study on what basically a lesson book is and how a contextual teaching strategy is applied in writing a lesson book of the language called Bahasa Indonesia. In involving students in language learning and literary activity, a competency to be developed is related to how to guide them so that they are motivated to learn through the lesson book. A basic principle to be paid attention to is that students are able to build up experiences in language and literary activities on the basis of their initial experience.

The study indicates the following results. First, a lesson book is a handbook for students at a level of formal education and used as an instructional medium related to a certain subject matter (such as Bahasa Indonesia). Second, such a book occupies a very important position as a store of knowledge of various aspects of life, has a meaningful role in students' learning achievement, and constitutes a source of reference for the teacher. Third, that book should contain a foundation for a clear and contemporary viewpoint, materials that are adequate, systematically and gradually composed, presented via methods and means able to stimulate students to read books with interest, having enough depth providing them with help in solving academic problems, and enabling them to have a chance to ponder what they have learned, and also evaluation instruments enabling them to know the competency they have achieved. Fourth, the curriculum contains information of only the main competencies to be achieved and these still have to be interpreted, clarified, broken down, completed, enriched, and put together through a lesson book. Fifth, the students, teacher, teaching materials, ways of presenting them, and exercises are the important components of learning to be accommodated in a lesson book. Sixth, contextual teaching employs a strategy oriented to efforts of aiding and inspiring students by linking a standard of competency with a realworld situation. Seventh, the basic principles of a contextual teaching approach are problem-based learning, context-based learning, difference-based learning, learning based on individuals, learning based on groups, and learning based on authentic evaluation. Eighth, a contextual teaching strategy could be manifested in a lesson book of Bahasa Indonesia by providing such activities as investigation, exploration, inquiry, model making, construction, and reflection. Ninth, an application of such a strategy should be in a concrete form to enable students to build up effective new experiences.
\end{abstract}

Keywords: lesson book of Bahasa Indonesia, contextual dimension, contextual strategy 


\section{A. PENDAHULUAN}

Upaya-upaya peningkatan mutu pendidikan melalui perbaikan mutu proses pembelajaran (di ruang kelas, di laboratorium, di lapangan, dan sebagainya) merupakan inovasi pendidikan yang harus terus dilakukan. Salah satu inovasi adalah mengubah paradigma pembelajaran dari pembelajaran yang terpusat pada guru kepada pembelajaran yang terpusat pada siswa. Pendekatan pembelajaran yang berbasis mengajar diubah ke dalam bentuk pembelajaran berbasis belajar. Ciri utama pembelajaran berbasis belajar adalah terbangunnya kemandirian siswa untuk membangun pengetahuan di dalam benaknya sendiri dari berbagai variasi informasi melalui suatu interaksi dalam proses pembelajaran.

Selain guru yang harus membantu siswa untuk membangun pengetahuannya, diperlukan sarana belajar yang efektif. Salah satu sarana yang paling penting adalah penyediaan buku pelajaran sebagai rujukan yang baik dan benar bagi siswa. Penyertaan buku ini sangat penting karena buku teks pelajaran merupakan salah satu sarana yang signifikan dalam menunjang proses kegiatan pembelajaran. Buku teks pelajaran yang dimaksud adalah buku yang menjadi pegangan siswa, baik siswa pada jenjang Taman Kanakkanak, Sekolah Dasar, Sekolah Menengah Pertama, Sekolah Menengah Atas, Sekolah Menengah Kejuruan, Sekolah Luar Biasa, maupun Perguruan Tinggi.

Buku teks pelajaran yang ada di lapangan, ditinjau dari jumlah, jenis, maupun kualitasnya sangat bervariasi. Sementara itu, buku teks pelajaran, pada umumnya, menjadi rujukan utama dalam proses pembelajaran. Guru di lapangan seringkali tidak merujuk pada kurikulum dalam perencanaan dan implementasi pembelajarannya, tetapi merujuk pada buku teks pelajaran yang digunakan. Dengan demikian, buku teks pelajaran haruslah disusun sebaik dan sebenar mungkin, terutama dalam kaitannya dengan konsep dan aplikasi konsep, agar tidak menjadi sumber pembodohan, melainkan menjadi sumber pencerdasan anak didik.
Hal demkian berlaku pula untuk buku teks pelajaran bahasa Indonesia. Yang menjadi persoalan adalah bagaimana mengembangkan buku teks pelajaran yang mampu merangsang siswa untuk membangun pengetahuan (pengalaman) di dalam benaknya sendiri?

\section{B. PENGERTIAN DAN KEDUDUKAN BUKU TEKS PELAJARAN}

Dalam berbagai literatur asing, buku pelajaran diistilahkan dengan textbook (selanjutnya istilah yang digunakan adalah buku pelajaran). Buku pelajaran menurut beberapa ahli adalah media pembelajaran (instruksional) yang dominan peranannya di kelas; media penyampaian materi kurikulum; dan bagian sentral dalam suatu sistem pendidikan (Patrick, 1988; Lockeed dan Verspoor, 1990; Altbach, dkk., 1991; Buckingham dalam Harris, ed., 1980; dan Rusyana, 1984). Secara lebih spesifik, Chambliss dan Calfee (1998) menjelaskan bahwa buku pelajaran adalah alat bantu siswa memahami dan belajar dari hal-hal yang dibaca. Buku pelajaran juga merupakan alat bantu memahami dunia (di luar dirinya). Buku pelajaran memiliki kekuatan yang luar biasa besar terhadap perubahan otak. Buku pelajaran dapat mengubah otak siswa. Kekuatan buku pelajaran yang mempengaruhi pengetahuan anak dan nilai adalah suatu asumsi agar buku pelajaran harus disusun secara bermutu.

Di dalam Peraturan Menteri Pendidikan Nasional Nomor 11 Tahun 2005 dijelaskan bahwa buku (teks) pelajaran adalah buku acuan wajib untuk digunakan di sekolah yang memuat materi pembelajaran dalam rangka peningkatan keimanan dan ketakwaan, budi pekerti dan kepribadian, kemampuan penguasaan ilmu pengetahuan dan teknologi, kepekaan dan kemampuan estetis, potensi fisik dan kesehatan yang disusun berdasarkan standar nasional pendidikan.

Berdasarkan penjelasan di atas dapat disimpulkan bahwa buku pelajaran adalah buku yang dijadikan pegangan siswa pada jenjang tertentu sebagai media pembelajaran (instruksional), berkaitan dengan bidang studi 
tertentu. Buku pelajaran merupakan buku standar yang disusun oleh pakar dalam bidangnya, biasa dilengkapi sarana pembelajaran (seperti pita rekaman), dan digunakan sebagai penunjang program pembelajaran.

Kedudukan buku teks pelajaran sangatlah penting, baik bagi siswa maupun guru. Karena tingkat kepentingan itulah buku teks pelajaran haruslah layak untuk dijadikan tempat beroleh pengalaman.

Buku teks pelajaran dapat dipandang sebagai simpanan pengetahuan tentang berbagai segi kehidupan (Pusat Perbukuan, 2005). Karena sudah dipersiapkan dari segi kelengkapan dan penyajiannya, buku teks pelajaran itu memberikan fasilitas bagi kegiatan belajar mandiri, baik tentang substansinya maupun tentang caranya. Dengan demikian, penggunaan buku teks pelajaran oleh siswa merupakan bagian dari budaya buku, yang menjadi salah satu tanda dari masyarakat yang maju.

Melalui kegiatan membaca buku, seseorang dapat memperoleh pengalaman tak langsung yang banyak sekali (Suryaman dan Utorodewo, 2006). Memang, dalam pendidikan merupakan hal yang berharga jika siswa dapat mengalami sesuatu secara langsung. Akan tetapi, banyak bagian dalam pelajaran yang tidak dapat diperoleh dengan pengalaman langsung. Karena itu, dalam belajar di sekolah, dan sesungguhnya juga, dalam kehidupan di luar sekolah, mendapatkan pengalaman tidak langsung itu sangat penting. Menurut Rusyana dan Suryaman (2004) kemajuan peradaban masa sekarang banyak mendapat dukungan dari kegiatan membaca buku. Karena itulah, penyiapan buku teks pelajaran patut dilakukan dengan sebaik-baiknya.

Dipandang dari hasil belajar, buku teks pelajaran itu mempunyai peran penting. Berbagai hasil penelitian menunjukkan bahwa buku pelajaran berperan secara maknawi dalam prestasi belajar siswa. Dalam Laporan World Bank (1995) mengenai Indonesia ditunjukkan bahwa tingkat kepemilikan siswa akan buku dan fasilitas lain berkorelasi dengan prestasi belajar siswa. Pernyataan tersebut diperkuat oleh Supriadi (1997) yang menyatakan bahwa tingkat kepemilikan siswa akan buku berkorelasi positif dan bermakna dengan prestasi belajar. Di Filipina, peningkatan rasio kepemilikan buku siswa dari $1: 10$ menjadi $1: 2$ di kelas 1 dan 2 secara signifikan meningkatkan hasil belajar siswa (World Bank, 1995).

Dipandang dari proses pembelajaran pun demikian. Jika tujuan pembelajaran adalah untuk menjadikan siswa memiliki berbagai kompetensi, untuk mencapai tujuan tersebut, siswa perlu menempuh pengalaman dan latihan serta mencari informasi. Alat yang efektif untuk itu adalah buku teks pelajaran sebab pengalaman dan latihan yang perlu ditempuh dan informasi yang perlu dicari, begitu pula tentang cara menempuh dan mencarinya, disajikan dalam buku teks pelajaran secara terprogram.

Walaupun buku teks pelajaran diperuntukkan bagi siswa, guru pun terbantu. Pada waktu mengajar guru dapat mempertimbangkan pula apa yang tersaji dalam buku teks pelajaran. Guru memiliki kebebasan dalam memilih, mengembangkan, dan menyajikan materi. Semua itu merupakan wewenang dan kewajiban profesionalnya.

Manfaat yang begitu besar tesebut tidaklah akan diperoleh manakala buku teks pelajaran yang disusun tidak layak. Artinya, buku itu tidak mencerminkan manfaat-manfaat yang digambarkan tadi. Oleh karena itu, para penulis buku pelajaran harus merancang buku secara serius dengan memperhatikan implikasi paparan manfaat di atas berikut ini (Greene dan Petty, 1971).

Pertama, buku pelajaran haruslah memiliki landasan sudut pandang yang jelas dan mutakhir. Buku teks pelajaran yang baik adalah buku yang memiliki suatu sudut pandang yang tangguh dan modern mengenai suatu pengajaran dan buku yang memeragakan sesuatu bahan pengajaran secara aplikatif.

Kedua, buku pelajaran haruslah berisi materi yang memadai. Buku pelajaran yang baik adalah buku pelajaran yang menyajikan materi yang kaya, bervariasi, mudah dibaca, 
serta sesuai dengan minat dan kebutuhan siswa. Dampak dari buku yang demikian adalah menjadi sumber pemecahan masalah akademis, memicu siswa untuk membaca, menyenangkan, menstimulasi kreativitas anak, dan sebagainya.

Ketiga, buku teks pelajaran haruslah berisi materi yang disusun secara sistematis dan bertahap. Sistematis dalam arti materi disajikan dengan memperhatikan kemudahan pemahaman siswa dalam hal penjelasan, penggambaran, dan pengorganisasian disusun secara sistematis; pengungkapan dilakukan secara lugas (tidak berbelit-belit); istilah diberi penjelasan dan atau contoh; penggunaan kata dan istilah dalam bahasa asing dan atau bahasa daerah yang tidak relevan dihindari; penyajian mendorong keaktifan siswa untuk berpikir dan belajar dengan cara bervariasi (misalnya: ilustrasi, kuis, dan lain-lain); menantang siswa untuk mencari sumber-sumber belajar lain; diikuti dengan sumber rujukan yang lengkap. Bahan kajian yang berkaitan dihubungkan satu sama lain secara terpadu, baik intrapelajaran maupun interpelajaran. Penempatan pelajaran dalam keseluruhan buku dilakukan secara tepat. Bertahap dalam arti materi yang disajikan diperhatikan dari segi urutan, seperti dari mudah ke sulit, dari sederhana ke rumit, dari umum ke khusus atau dari khusus ke umum, dari bagian ke keseluruhan, dan sebagainya.

Keempat, buku teks pelajaran haruslah berisi materi yang disajikan dengan metode dan sarana yang mampu menstimulasi siswa untuk tertarik membaca buku. Misalnya, disajikan gambar yang mampu merangsang siswa untuk menemukan jawaban dari suatu latihan, memperkonkret pengalaman belajar siswa, dan memungkinkan siswa untuk membuktikannya di lingkungan sekitar atau melalui penelitian sederhana.

Kelima, buku pelajaran haruslah berisi materi yang mendalam sehingga memungkinkan siswa terbantu di dalam memecahkan masalah-masalah akademis yang dihadapinya. Misalnya, pada saat siswa mengerjakan tugas atau latihan, kedalaman pengerjaan atau pemecahan masalah terakomodasi oleh buku, baik disebabkan buku itu memuat hal yang diperlukan siswa atau adanya petunjuk untuk mendapatkan rujukanrujukan yang memungkinkan masalah itu terpecahkan.

Keenam, buku pelajaran haruslah berisi alat evaluasi yang memungkinkan siswa mampu mengetahui kompetensi yang telah dicapainya. Tingkat pencapaian kompetensi dapat dijadikan umpan balik bagi siswa apakah siswa harus memperdalam lagi bahan tersebut atau melanjutkan kepada bahan berikutnya yang lebih tinggi.

Ketujuh, buku pelajaran haruslah berisi bahan yang memungkinkan siswa memiliki kesempatan untuk menggelitik mata hatinya atas hal yang telah dipelajarinya. Manfaat apa yang diperoleh siswa setelah membaca bahan dan berlatih atas bahan itu, merupakan pertanyaan yang sebaiknya muncul pada diri siswa. Dengan kata lain, alat ini dapat dijadikan bahan refleksi siswa atas segala masalah akademis yang selama ini dipelajarinya.

\section{PENGENALAN B U KU TEKS PELAJARAN}

Agar buku teks pelajaran dapat digunakan dengan baik, perlulah dilakukan pengenalan oleh siswa terhadap buku yang akan dipelajarinya. Hendaknya disediakan waktu bagi para siswa untuk menelaah bagian-bagian yang ada dalam buku teks pelajaran, mulai dari judul buku itu, daftar isi, judul-judul setiap bab, hingga bagian akhir dari buku itu. Setelah menelaah, siswa mendiskusikannya dengan sesamanya. Juga, mereka diminta untuk mengemukakan apa yang diharapkannya atau diperkirakan dapat diketahui dari bab demi bab buku itu.

Penelaahan sepintas tentang isi itu akan menimbulkan perhatian para siswa untuk memahami isi buku itu. Dapat dianjurkan kepada mereka untuk membaca bagian yang paling diminatinya.

Selanjutnya, untuk mempelajari bagian yang dipilih sebagai materi tertentu, dapat digunakan berbagai cara. Penulis dapat 
menunjukkan cara-cara untuk dicoba oleh para siswa. Misalnya, membaca judul bab, lalu menemukan kalimat topik pada paragraf demi paragraf. Setelah itu, membacanya dengan cermat, memahami pokok-pokok yang terkandung di dalam bab itu.

Mengingat penggunaannnya dalam kegiatan belajar, buku teks pelajaran perlu disusun dengan cara yang dapat memenuhi keperluan belajar tersebut. Menurut Pusat Perbukuan (2005) kriterianya adalah isinya benar dari segi keilmuan, disusun secara sistematis, mengandung informasi yang kaya dan relevan, terdapat kesinambungan, kesaksamaan, keteraturan, serta keseimbangan.

Mutu dari buku teks pelajaran tergantung pada kegunaannya untuk keperluan belajar siswa. Makin banyak keperluan yang dapat dilayani, semakin baik. Misalnya, memberi kesempatan kepada siswa untuk belajar sesuai dengan kecepatannya sendiri; untuk melakukan pendalaman; untuk mengadakan pemeriksaan lagi dalam mengingat sesuatu; untuk mencatat hal-hal penting bagi keperluan lain; untuk menyaksikan gambar, diagram, grafik, tabulasi, dan sebagainya.

\section{H U B U N G A N B U K U T E K S

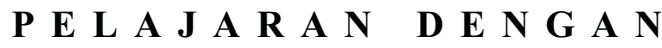 KURIKULUM}

Buku teks pelajaran mempunyai hubungan dengan kurikulum, tetapi hubungan itu tidak kaku. Kurikulum itu tidak bersifat menentukan segala sesuatu. Pada kurikulum pascakurikulum 1994, tidak lagi dikenal istilah kurikulum. Yang ada adalah standar kompetensi dan kompetensi dasar. Kurikulum baru dikenal di dalam satuan pendidikan.

Karena hanya yang pokok-pokok yang diberikan, diperlukan penafsiran, penjelasan, perincian, pelengkapan, pengayaan, dan pemaduan terhadap standar kompetensi dan kompetensi dasar itu, baik itu berkenaan dengan hasil belajar, indikator, maupun materi pokok. Inilah yang dimaksud dengan kurikulum satuan pendidikan, yang penyusunannya menjadi tugas guru dan penulis buku teks pelajaran.

Mengingat keadaan kurikulum sekarang yang tidak ketat menentukan segala sesuatu, makin besarlah tanggung jawab guru dan penulis buku teks pelajaran untuk mengembangkan kurikulum itu. Para guru dan penulis buku teks pelajaran perlu memahami benar landasan-landasan yang digunakan dalam penyusunan kurikulum dan ke mana arahnya, agar penafsiran dan pengembangan yang dilakukan benar dari berbagai seginya.

Perubahan-perubahan yang terjadi, misalnya dianutnya paham baru dalam pendidikan, secara bertahap akan tercermin dalam materi dan susunan buku teks pelajaran. Karena itu, guru dan penulis buku teks pelajaran perlu menyadari dan memahami akan hakikat perubahan-perubahan yang terjadi.

\section{E. PEMBELAJARAN DAN BUKU TEKS PELAJARAN}

Pembelajaran dengan buku teks pelajaran merupakan dua hal yang saling melengkapi (Suryaman, 2006). Pembelajaran akan berlangsung secara efektif manakala dilengkapi dengan media pembelajaran, yakni - yang cukup penting - berupa buku teks pelajaran. Buku teks pelajaran dapat disusun serta digunakan dengan baik jika memperhatikan prinsip-prinsip dalam pembelajaran. Di dalam pembelajaran tersangkut masalah siswa, guru, materi bahan ajar, cara penyajian bahan ajar, serta latihan. Komponen ini harus tercermin di dalam buku teks pelajaran. Ketercerminan saja tidak cukup. Buku teks pelajaran harus berisi pula hasil pengolahan atas komponen-komponen tersebut dalam satu kesatuan yang padu sehingga materi bahan ajar, cara penyajian materi bahan ajar, dan latihan materi bahan ajar dapat dengan mudah dipahami dan dipraktikkan, baik oleh siswa maupun guru.

Sehubungan dengan itu, buku teks pelajaran juga harus mengakomodasi prinsipprinsip pembelajaran tersebut. Selama ini prinsip yang mendapat perhatian besar adalah materi bahan ajar. Perhatian yang berlebihan terhadap materi bahan ajar serta mengabaikan 
komponen yang lain mengakibatkan buku teks pelajaran lebih mengutamakan hasil, dan mengabaikan proses. Orientasi yang berlebihan terhadap hasil malahan mengakibatkan Nilai Ebtanas Murni (NEM) pada masa lalu dan nilai ujian nasional pada masa kini belum mencapai harapan yang memuaskan. Buku teks pelajaran hanya difungsikan sebagai tempat yang mengandung materi bahan ajar yang dapat dihapalkan. Kemampuan siswa pun hanya sebatas kemampuan menghapal. Ketika dihadapkan pada masalah yang berbeda, siswa tidak mampu memecahkannya. Akhirnya, buku teks pelajaran hanyalah memperkuat anggapan bahwa belajar berbahasa adalah belajar tentang pengetahuan bahasa, bukan belajar membaca, menulis, berbicara, dan mendengarkan; belajar bersastra adalah belajar tentang pengetahuan sastra, bukan belajar berapresiasi, berekspresi, maupun berkreasi dengan sastra; dan sebagainya

Pola penyusunan buku teks pelajaran yang demikian dianggap tidak berhasil, bukan disebabkan oleh kurikulum atau apapun, melainkan oleh ketidaksesuaiannya dengan hakikat buku teks pelajaran. Pada hakikatnya buku teks pelajaran merupakan media pembelajaran. Sebagai media, buku itu harus berisi materi bahan ajar, cara penyajian bahan ajar, dan model latihan bahan ajar. Materi yang dijadikan bahan ajar harus disajikan dengan cara tertentu sehingga siswa memiliki kemampuan berkenaan dengan pemahaman, keterampilan, dan perasaan. Sebagai refleksi atas kemampuan tersebut, siswa dapat memecahkan persoalan-persoalan yang diajukan di dalam latihan. Begitupun bagi guru. Buku teks pelajaran harus mampu membantu guru berkenaan dengan cara mengajarkan serta menguji kemampuan siswa berkenaan dengan materi tersebut.

Secara teoretis, guru berpengalaman dapat mengajarkan materi tanpa buku teks pelajaran. Akan tetapi, cara demikian tidak akan berlangsung lama. Banyak guru yang tidak sempat untuk menulis materi pelengkap sehingga mereka hanya berpijak pada buku teks pelajaran. Artinya, buku teks pelajaran memiliki posisi yang sangat penting dalam kelas. Oleh karena itu, buku teks pelajaran harus disusun seefektif dan seefisien mungkin sehingga siswa dan guru terbantu dalam belajar dan mengajar di rumah maupun di kelas.

Penyajian materi merupakan tahap kedua setelah materi tersedia. Materi itu dapat meliputi pengetahuan seperti fakta, konsep, prinsip, dan prosedur; keterampilan, seperti kemampuan menerapkan prosedur; serta sikap, seperti nilai. Ibarat seorang juru masak, penyediaan materi merupakan tahap awal sebelum memasak. Rasa, aroma, dan kelezatan suatu masakan tergantung kepada cara pengolahan juru masak dan cara penyajian pramusaji. Antara juru masak yang satu dengan juru masak yang lain akan menghasilkan masakan dengan rasa, aroma, dan kelezatan yang berbeda sekalipun bahan sama. Semua tergantung kepada pengalaman, keterampilan, wawasan, dan sebagainya dari juru masak.

Hal demikian terjadi pula di dalam penyusunan buku pelajaran. Setelah bahan materi seperti dikemukakan di atas tersedia, penulis harus mengolahnya agar buku pelajaran yang disusunnya menghasilkan menu yang mampu membangkitkan selera pembaca (siswa). Kemampuan ini tampak ketika siswa dipermudah, dibangkitkan minatnya, dikembangkan daya tariknya, dirangsang skematanya, dikembangkan daya pikir dan ciptanya, ditumbuhkan aktivitas dan kreativitasnya, serta ditimbulkan keinginan untuk mencoba oleh buku pelajaran. Tentu pula buku yang ditulis oleh seseorang akan berbeda dengan penulis yang lainnya. Hal ini tergantung kepada pengalaman, keterampilan, wawasan, dan sebagainya dari penulis.

Berdasarkan paparan di atas tampak bahwa penyajian materi berkenaan dengan penataan materi di dalam buku pelajaran. Penataan ini dimaksudkan agar mudah, menarik, membangkitkan minat, membangun skema, mengembangkan daya pikir dan daya cipta, beragam, menimbulkan aktivitas dan kreativitas, menimbulkan keinginan untuk mencoba, dan sebagainya. 
Penyajian materi di dalam buku pelajaran tidak hanya didasarkan persepsi penulis semata. Cara mengolah dan kemudian menyajikannya di dalam buku pelajaran, haruslah didasarkan atas pandangan teori belajar. Artinya, peguasaan teori belajar menjadi sangat signifikan untuk dikuasai oleh penulis buku pelajaran. Belajar adalah bagaimana cara siswa membangun pengalaman baru berdasarkan pengalaman awal. Prinsip ini mengarahkan kita bahwa sumber belajar yang paling otentik adalah pengalaman. Menurut Covey (2006) belajar merupakan upaya untuk mengilhami diri kita dan orang lain. Caranya adalah kenali diri dan dengarkan hati nurani kita. Pengenalan diri dan penyertaan hati nurani menyiratkan betapa tingginya nilai pengalaman.

Sejak tahun 1916, John Dewey telah menyatakan bahwa siswa akan belajar dengan baik jika yang dipelajarinya terkait dengan apa yang telah diketahuinya. Para ahli psikologi belajar mutakhir pun semakin memperkuatnya. Piaget, misalnya, dengan teori skemanya menjelaskan bahwa perkembangan intelektual anak muncul melalui proses penciptaan pengetahuan baru berdasarkan pengetahuan yang sudah ada pada diri si anak. Ia memberikan contoh tentang seorang anak kecil dari kota yang diajak berjalan-jalan oleh ayahnya ke suatu desa. Ia melihat seekor sapi di ladang. Kemudian anak itu berkata: "Ayah, lihat, itu ada anjing besar" (Barry, 1977 dan Suryaman, 2001).

Pengambilan kesimpulan "anjing besar" didasarkan pengetahuan awal anak tentang anjing, namun pengetahuan anak tentang sapi belum dikenalnya. Di sini anak mencoba menempatkan stimulus yang baru (sapi) pada pengetahuan awalnya. Stimulus baru itu kira-kira mirip dengan seekor anjing (yang sudah dikenal) sehingga ia mengidentifikasikan objek tersebut sebagai seekor anjing. Si anak belum mampu membedakan antara sapi dengan anjing tetapi sudah mampu melihat kesamaannya.

Begitupun dengan Ausubel (Biehler, 1978) yang menyatakan bahwa perlunya pengorganisasian awal (advanced organizer) sebagai jembatan konseptual antara sesuatu yang telah diketahui dengan sesuatu yang baru. Syaratnya, sesuatu yang telah diketahui itu stabil, jelas, terbedakan dari yang lain, serta berkaitan dengan hal yang baru.

Piaget kemudian memaknai belajar sebagai pemrosesan pengalaman yang secara konstan mengalami pemantapan sesuai dengan informasi baru yang diperoleh. Semakin banyak pengalaman, semakin bertambah pula penyempurnaan skema seseorang. Para pakar teori skema memastikan bahwa latar belakang pengalaman yang kaya akan sangat membantu keberhasilan belajar. Pengalaman yang kaya itu bisa diperoleh dengan berbagai cara, di antaranya dengan jalan membaca, khususnya membaca buku teks pelajaran. Semakin banyak seseorang membaca, akan semakin meningkat pula kemampuan membacanya. Hasil penelitian Yap (1978) mendukung pernyataan tersebut, yakni tingkat keterampilan membaca seseorang ditentukan oleh $65 \%$ banyaknya membaca.

\section{F. Dimensi-dimensi Kontekstual}

Teori belajar yang dikembangkan oleh Jonh Dewey menjadi inspirasi bagi para ahli pendidikan di dalam melahirkan teori-teori belajar lainnya, termasuk teori strategi pembelajaran. Salah satu teori pembelajaran yang diinspirasi oleh teori Dewey adalah pembelajaran kontekstual.

Pembelajaran kontekstual merupakan strategi yang diarahkan kepada upaya membantu atau menginspirasi siswa melalui proses pengaitan suatu standar kompetensi dengan situasi dunia nyata. Proses yang dapat dikembangkan adalah melalui dorongan ke arah berkembangnya pengalaman baru dengan cara memadukan antara pengetahuan dengan penerapan di dalam kehidupan siswa. Proses demikian akan mengakrabkan siswa dengan lingkungannya, baik lingkungan keluarga, masyarakat, maupun dunia kerja. Harapannya adalah siswa menjadi lebih termotivasi untuk belajar(Johnson, 2002). 
Prinsip-prinsip dasar di dalam pendekatan kontekstual adalah belajar berbasis masalah, belajar berbasis konteks, belajar berbasis perbedaan, belajar berbasis individu, belajar berbasis kelompok, dan belajar berbasis penilaian otentik (Johnson, 2002). Berikut ini paparan sepintas tentang strategi tersebut:

Pembelajaran kontekstual dapat dimulai dengan suatu masalah nyata yang disimulasikan. Masalah nyata ini dapat dipecahkan siswa melalui keterampilan berpikir kritis dan melalui suatu pendekatan sistemik untuk menemukan peta masalah. Masalah-masalah nyata itu haruslah bermakna bagi siswa, yang dapat diperoleh dari lingkungan keluarga, pengalaman di sekolah, tempat kerja, dan masyarakat.

Di dalam teori kognisi, pengetahuan bukanlah sesuatu yang terpisah dari konteks sosial maupun fisik yang terus berkembang. Bagaimana dan di mana seseorang memperoleh dan menciptakan pengetahuan merupakan unsur yang sangat penting untuk diperhatikan. Pengalaman melalui pembelajaran kontekstual diperkaya manakala keterampilan belajar berkembang melalui konteks, seperti sekolah, masyarakat, tempat kerja, dan keluarga.

Seorang siswa adalah seseosok pribadi yang khas. Kekhasan ini bisa tampak melalui sikap, perilaku sosial, dan cara pandang. Dengan sendirinya, kekhasan ini menjadi sumber perbedaan di dalam kumunitas belajar. Perhatian terhadap kekhasan pribadi siswa bukan untuk membuat jarak hubungan sosial menjauh, tetapi haruslah menjadi modal dasar yang kuat untuk membangun keterampilan interpersonal, berpikir terbuka, dan sebagainya.

Belajar merupakan proses sepanjang hayat. Prinsip ini harus terinternalisasi pada diri pembelajar sehingga belajar menjadi suatu kebutuhan. Belajar tidak lagi menjadi sebuah beban bagi siswa. Jika ini sudah tumbuh, siswa akan menjadi pembelajar yang semakin sadar. Kesadaran ini menjadi dasar bagi tumbuhnya kemampuan mengolah informasi dan kemampuan mencari strategi-strategi pemecahan masalah dengan memanfaatkan latar belakang pengalamannya. Implikasinya pembelajar akan terbiasa dengan uji coba, membiasakan diri untuk merenungkan proses, menyediakan waktu yang cukup, dan terbangunnya belajar mandiri di dalam memecahkan masalah.

Siswa akan dipengaruhi oleh dan akan berkontribusi terhadap pengetahuan dan keyakinan yang lain. Kelompok belajar atau masyarakat belajar di sekolah atau luar sekolah merupakan tempat yang efektif untuk berbagi pendapat atau pengalaman. Pengondisian yang efektif untuk selalu membiasakan diri melalui belajar kelompok akan banyak membantu siswa di dalam belajar.

Pembelajaran kontekstual merupakan proses untuk menerapkan kemampuan akademik dan kecakapan yang bermakna berdasarkan kehidupan nyata atau konteks yang otentik. Oleh karena itu, penilaian yang dikembangkan haruslah mewadahi prinsip tersebut. Penilaian yang dimaksud adalah penilaian otentik. Penilaian ini memberikan kesempatan yang luas kepada siswa untuk menunjukkan segala hal yang telah dipelajari selama belajar. Bentuk-bentuk penilaian otentik adalah portofolio, tugas kelompok, demonstrasi, dan laporan tertulis.

Agar strategi kontekstual itu efektif sehingga siswa mampu membangun pengetahuan atau pengalaman berbahasa dan bersastra diperlukan cara. Cara ini dapat diwujudkan melalui penyediaan aktivitasaktivitas belajar di dalam buku teks pelajaran bahasa Indonesia. Cara-cara itu di antaranya adalah investigasi, eksplorasi, inkuiri, pemodelan, konstruksi, dan refleksi.

\section{G. PENDEKATAN KONTEKSTUAL DI DALAM BUKU TEKS PELAJARAN BAHASAINDONESIA}

Mata pelajaran bahasa Indonesia berada dalam lingkungan keilmuan bahasa dan sastra, khususnya keilmuan terapan berkenaan dengan berbahasa dan bersastra (Pusat Perbukuan, 2005). Dasar dari ilmu terapan ini haruslah dikuasai oleh para penulis buku pelajaran. Secara sederhana keilmuan terapan 
itu dapat dipaparkan melalui penjelasan berikut ini.

Dalam pembelajaran berbahasa dan bersastra dikehendaki terjadinya kegiatan berbahasa dan bersastra, yakni kegiatan menggunakan bahasa dan berapresiasi, berekspresi, serta berkreasi dengan karya sastra. Jadi, berbagai unsur bahasa, seperti kosakata, bentuk serta makna kata, bentuk serta makna kalimat, bunyi bahasa, dan ejaan, begitupun dengan berbagai unsur bersastra, seperti tokoh, latar, tema di dalam prosa dan drama atau unsur bentuk dan unsur isi di dalam puisi tidaklah diajarkan secara berdiri sendiri sebagai unsur-unsur yang terpisah, melainkan dijelaskan dalam kegiatan berbahasa dan bersastra. Kegiatan berbahasa mencakup kegiatan mendengarkan (menyimak), kegiatan berbicara, kegiatan membaca, dan kegiatan menulis. Kegiatan bersastra mencakup kegiatan apresiasi, ekspresi, dan kreasi.

Kegiatan mendengarkan, berbicara, membaca, dan menulis serta kegiatan apresiasi, ekspresi, dan kreasi itu digunakan dalam berkomunikasi, yaitu oleh seseorang dalam berhubungan dengan yang lainnya. Bahasa dan sastra dalam berkomunikasi digunakan untuk bertukar pikiran, perasaan, pendapat, imajinasi, dan sebagainya sehingga terjadi kegiatan sambut-menyambut.

Kegiatan berbahasa dan bersastra itu serempak dilakukan dalam kegiatan lain, baik kegiatan jasmani maupun kegiatan rohani. Kegiatan berbahasa dan bersastra dilakukan serempak dengan kegiatan menggunakan tangan, kaki, kepala, pancaindra, dan sebagainya. Kegiatan berbahasa dan bersastra pun dilakukan serempak dengan kegiatan merasa, berpikir, berimajinasi, dan sebagainya. Kegiatan berbahasa, kegiatan bersastra, dan kegiatan berbuat itu terjadi dalam konteks, berupa tempat, waktu, dan suasana. Di dalamnya terdapat tanah, air, udara, cahaya, tumbuhan, binatang; manusia dengan masyarakat dan budayanya.

Di dalam kurikulum pascakurikulum 1994 keilmuan terapan itu diformulasikan ke dalam istilah standar kompetensi dan kompetensi dasar. Standar kompetensi berbahasa dan bersastra adalah kualifikasi minimal peserta didik yang digambarkan melalui penguasaan sikap, pengetahuan, dan keterampilan berbahasa dan bersastra yang harus dicapai pada setiap tingkat dan atau semester (BSNP, 2006). Standar kompetensi ini terdiri atas sejumlah kompetensi dasar sebagai acuan baku yang harus dicapai dan berlaku secara nasional. Kompetensi dasar adalah sejumlah kemampuan yang harus dikuasai peserta didik dalam berbahasa dan bersastra sebagai rujukan di dalam penyusunan indikator kompetensi. Indikator kompetensi adalah perilaku yang dapat diukur dan atau diobservasi untuk menunjukkan ketercapaian kompetensi dasar tertentu yang menjadi acuan penilaian di dalam berbahasa dan bersastra. Dengan demikian, dasar pertama penulis di dalam menyusun buku teks pelajaran bahasa Indonesia adalah standar kompetensi dan kompetensi dasar. Kemudian, penulis menerjemahkannya ke dalam indikator berdasarkan pandangan keilmuan terapan berbahasa dan bersastra.

Penerjemahan tersebut, selain berdasarkan keilmuan terapan berbahasa dan bersastra, harus pula didasarkan atas teori belajar, khususnya dari segi perkembangan jiwa peserta didik. Cara pandang ini juga akan membantu penulis dalam hal tahapan kompetensi dasar yang tepat untuk siswa SD, SMP, maupun SMA. Artinya, kompetensi dasar mungkin sama, tetapi indikator berbeda, yakni disesuaikan dengan perkembangan kejiwaan siswa.

Para penulis haruslah menerjemahkan standar kompetensi dan kompetensi dasar ke dalam bahasa yang sederhana dan mudah dipahami, seperti mendengarkan cerita, memerankan percakapan, membaca cepat, atau membuat catatan harian. Penamaan ini dapat disusun melalui subjudul pada setiap bab atau pelajaran. Kemudian, istilah indikator dapat kita susun melalui tujuan pembelajaran yang terletak setelah subjudul. Misalnya, untuk subjudul mendengarkan cerita terdapat tujuan yang berbunyi "Kamu akan menjelaskan 
kejadian yang dialami pelaku di dalam cerita"; untuk subjudul membaca memindai terdapat tujuan yang berbunyi "Kamu akan diajak mencari nomor telepon pada buku telepon".

Penerjemahan terhadap standar kompetensi dan kompetensi dasar dapatlah didasarkan atas keilmuan terapan berbahasa dan bersastra serta teori belajar. Artinya, buku yang ditulis tetaplah mengandung keilmuan terapan, baik itu berkenaan dengan sistem membaca; menulis puisi; prinsip-prinsip jurnalistik atau ilmiah dalam mendengarkan berita atau wawancara; dan sebagainya. Namun, keilmuan itu haruslah aplikatif dan mungkin tidak eksplisit dikenali sebagai sebuah keilmuan formal.

Sebagai contoh, dalam buku dikembangkan cara berlatih membaca cepat. Cara berlatih, seperti mencari: nomor telepon, kata dalam kamus, jadwal siaran televisi, jadwal perjalanan, merupakan teori aplikatif untuk membaca memindai. Akan tetapi, ada pula cara membaca memindai prosa, yakni mencari informasi topik tertentu dalam suatu bacaan. Artinya, kita mencari informasi yang dibutuhkan dengan mencari terlebih dahulu bagian dari bacaan yang memuat informasi tersebut.

Langkah-langkahnya adalah pertama, carilah kata kunci yang dibutuhkan. Kedua, kenalilah organisasi dan struktur bacaan untuk memperkirakan letak kata atau istilah yang dicari. Lihat gambar, grafik, tabel, jika disediakan. (Jika kita memindai buku, cobalah cari kata atau istilah itu melalui daftar isi dan indeks). Ketiga, gerakkanlah mata dengan cepat. Ada dua cara: (1) seperti anak panah langsung ke tengah bacaan dan meluncur ke bawah atau (2) dengan cara pola S atau zig-zag. Keempat, setelah menemukan letak kata atau istilah yang dicari, lambatkan kecepatan membaca untuk memperoleh informasi yang dibutuhkan.

Melalui paparan seperti di atas tampak bahwa teori membaca cepat tidak lagi berupa penjelasan dalam bentuk definisi formal beserta seperangkat penjelasannya, seperti ciri-ciri, klasifikasi, dan sebagainya, melainkan sudah aplikatif. Bahkan, teori aplikatif itu bisa jadi terdapat pada permintaan kepada siswa untuk melakukan sesuatu (latihan). Selain aplikatif, siswa pun dikondisikan untuk dapat menemukan sendiri berdasarkan stimulus (seperti petunjuk) yang diberikan. Cara demikianlah yang menjadi strategi pembelajaran yang efektif di masa kini, yakni siswa mampu membangun pengetahuan dan pengalaman sendiri berdasarkan stimulus yang diberikan (konstruktif).

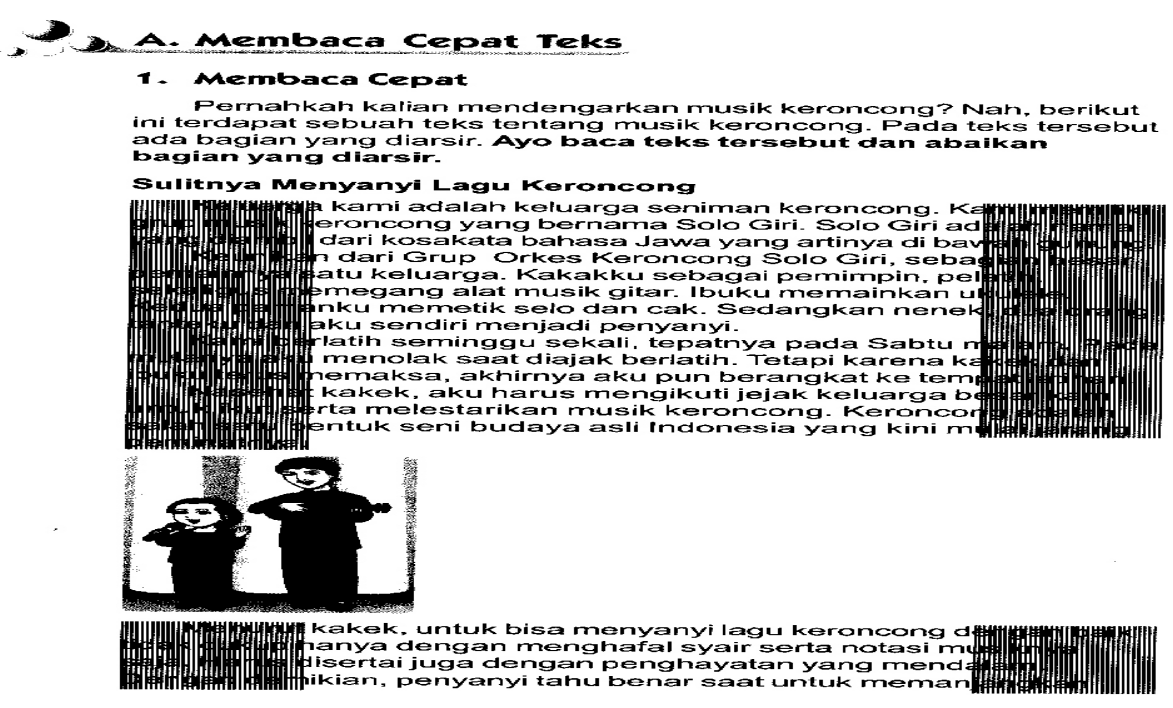


Contoh lain adalah stimulasi yang dapat membangun kembali pengalaman atau pengetahuan yang telah dimiliki siswa di dalam menulis puisi. Saat akan membangun kompetensi menulis puisi, misalnya, penulis dapat meminta siswa mengidentifikasi peristiwa yang pernah diindranya (dilihat, didengar, dirasakan, dicium, diraba), catatan pribadinya, atau cerita yang pernah dibacanya. Cara demikian termasuk ke dalam penyediaan aktivitas belajar melalui investigasi.

Melalui kompetensi dasar membaca intensif, misalnya, penulis dapat membuat stimulasi berupa mengamati bacaan, baik berkenaan dengan judul, pengarang, atau sumber rujukan. Berdasarkan hasil pengamatan, penulis dapat meminta siswa untuk membuat daftar pertanyaan tentang kirakira isi yang ada di dalam bacaan tersebut. Siswa pun kemudian mengajukan jawaban sementara berdasarkan pandangan pribadi. Jawaban sementara ini menjadi hipotesis. Untuk membuktikan apakah hipotesis itu benar atau tidak, penulis meminta siswa untuk membuktikannya melalui membaca keseluruhan bacaan sambil membandingkan dengan jawabannya (cara eksplorasi). Langkah terakhir adalah siswa menarik kesimpulan atas pembuktian itu. Kemudian, menyajikan sintesisnya diikuti dengan diskusi antarhasil temuan siswa lainnya. Stimulasi demikian, di dalam istilah pembelajaran kontekstual, dikenal dengan inkuiri (menemukan sendiri berdasarkan stimulasi yang konkret dari guru).

Setiap kegiatan yang harus dilaksanakan oleh siswa disertai dengan contoh dan pengertian mengenai tugas itu. Misalnya, jika siswa diminta untuk membuat rangkuman bacaan, pasti ada penjelasan terlebih dahulu, baik berupa contoh atau definisi operasional tentang apa yang dimaksudkan dengan rangkuman dan bagaimana contoh membuat rangkuman yang baik. Jadi, selalu disertakan contoh cara pembuatan rangkuman, cara mencari gagasan paragraf atau teks, cara mencari masalah, cara menandai penokohan dalam cerpen. Kemudian, siswa melakukan hal yang sama berdasarkan contoh. Siswa dituntun melalui pertanyaan yang akan membuat siswa menemukan jawaban bagi persoalan yang dihadapinya. Cara ini dikenal dengan strategi the copy of master (meniru adikarya).

Contoh lain, misalnya, di dalam pembelajaran menulis cerita pendek, penulis dapat memberikan contoh cerpen. Mula-mula siswa membaca cerpen tersebut, membuat bagan tokoh cerpen dilihat dari pola hubungan, mengidentifikasi waktu dan tempat kejadian, membuat ilustrasi visual setiap tokoh cerpen, menentukan apa yang dipermasalahkan, dan sebagainya. Pada pertemuan berikutnya, siswa sudah diminta mengganti tokoh dengan tokohtokoh dalam kehidupan sehari-harinya, membuat bagan hubungan antartokoh jika berbeda dengan bagan tokoh cerpen yang dibacanya, mengganti waktu dan tempat kejadian, mengganti permasalahan sesuai dengan yang dialami siswa, dan sebagainya. Kemudian, diikuti dengan menguraikannya secara naratif. Cara demikian merupakan penerapan modelling (pemodelan) di dalam pembelajaran kontekstual.

Di dalam satu bab atau satu pelajaran selalu terdiri atas beberapa kemampuan berbahasa dan beberapa kemampuan bersastra. Penyajian seperti ini mengandung arti bahwa antara kemampuan berbahasa dengan kemampuan bersastra saling terkait satu sama lain, saling mendukung, saling melengkapi, saling bersinergi untuk mengembangkan kompetensi yang lebih baik. Hal ini juga dimaksudkan agar keterpaduan menjadi cara efektif di dalam belajar berbahasa dan bersastra. Namun, pada beberapa buku yang terstandar konsep keterpaduan baru diartikan melalui penggunaan tema untuk setiap wacana yang dijadikan contoh pembelajaran. Untuk itu, penulis harus berupaya menerjemahkannya sehingga keterpaduan lebih bervariasi lagi. Misalnya, materi membuat catatan harian dijadikan dasar untuk menulis cerita pendek atau puisi.

Perlu diperhatikan juga bahwa, dalam kegiatan bersastra, tafsiran terhadap sebuah karya sastra, apakah itu puisi, cerpen, karya terjemahan, atau drama, tidak hanya satu 
kemungkinan tafsiran. Meskipun sudah disajikan sebuah contoh tafsiran, siswa harus diberi kesempatan untuk menafsirkan karya sastra tersebut sendiri. Masalahnya, tafsir setiap orang saat membaca sebuah karya sastra pasti tidak sama, sangat relatif berdasarkan pengalaman pribadi setiap orang. Oleh sebab itu, dalam menyajikan contoh penafsiran, sebaiknya, disajikan juga alasan bagi tafsiran itu. Misalnya, dengan mencuplik bagian dari karya sastra itu, dengan merujuk kepada kamus, dan sebagainya. Cara demikian merupakan upaya penyediaan aktivitas berupa investigasi.

Penulis haruslah mengondisikan siswa untuk berkelompok, baik kelompok kecil maupun besar. Kelompok ini penting agar siswa dapat menggunakan buku teks pelajaran optimal di luar kelas. Selain itu, siswa dapat memperkaya wawasannya dengan membagi tugas dalam kelompok untuk mencari sumber pengayaan lain.

Pengelompokan juga amat berguna di dalam mencapai kompetensi mendengarkan. Antarsiswa kegiatan mendengarkan dapat dilakukan. Misalnya, salah seorang teman di dalam kelompok belajar berperan menjadi pembaca berita. Teman lainnya mendengarkan sambil mencatat hal-hal penting berkenaan dengan berita, seperti apa, siapa, kapan, di mana, mengapa, atau bagaimana. Untuk guru, wacana bahan mendengarkan di dalam buku teks pelajaran dapat direkam kemudian siswa mendengarkan rekaman tersebut.

Melalui pembelajaran pementasan drama, misalnya, penulis dapat menstimulasi siswa melalui kelompok untuk melakukan brainstorming intrakelompok tentang naskah drama yang akan dipentaskan. Mereka diminta untuk berbagi pengalaman. Di samping itu, mereka juga akan belajar membentuk suatu organisasi dalam menciptakan kerja sama. Cara demikian dikenal dengan penyediaan aktivitas berupa inkuiri, eksplorasi, dan investigasi melalui learning community (masyarakat belajar).

Pada setiap akhir penyelesaian suatu bab atau pelajaran, siswa distimulasi untuk merasakan, membayangkan, memikirkan hal- hal yang telah dipelajarinya. Misalnya, melalui pertanyaan "Apa yang kamu rasakan setelah mempelajari bab tertentu?", “Apa yang terbayang dalam diri kamu jika mampu menulis cerpen?", "Apakah kamu juga terdorong untuk mulai membaca beragam bacaan?", "Mengapa saya menyukai itu?", "Bagaimana agar saya bisa mengirimkan tulisan ke media massa?, dan sebagainya. Jawaban-jawaban itu kemudian dirangkai dalam satu tulisan, baik berupa simpulan, saran, pendapat, dan sebagainya. Cara ini merupakan bentuk refleksi atas hal yang telah dipelajarinya.

Penulis haruslah mengondisikan siswa agar terjadi penilaian antarsiswa, mengetahui ada-tidaknya manfaat yang telah dipelajarinya, mengukur kompetensi dirinya, baik kognitif, afektif, maupun psikomotorik, memberi tahu bagaimana cara memublikasikan hasil, baik di papan majalah dinding, atau di media massa, dan sebagainya. Berkenaan dengan keterampilan menulis, misalnya, penulis haruslah mengingatkan kembali atas hasil tulisan pada kompetensi sebelumnya sehingga siswa sendiri mampu mengenali perkembangan kompetensi menulisnya.

\section{H. PENUTUP}

Secara umum dimensi-dimensi kontekstual di dalam penulisan buku teks pelajaran bahasa Indonesia akan mengondisikan siswa belajar mandiri berkenaan dengan kegiatan berbahasa dan bersastra. Tingkat ketergantungan kepada orang lain dengan sendirinya akan menurun. Siswa pun akan merasakan betapa belajar melalui buku teks pelajaran bahasa Indonesia menyenangkan. Arah belajar serta ketercapaian kompetensi semakin jelas. Belajar berbahasa dan bersastra bukan lagi menjadi beban karena adanya manfaat dan makna yang dapat diperoleh siswa. Karena belajar berbasis masalah, siswa akan terdorong untuk belajar memecahkan masalah, baik secara individu maupun kelompok. 


\section{DAFTAR PUSTAKA}

Allwright, R. L. (1990). "What do we want teaching materials for?" dalam R. Rossner and R. Bolitho, (Eds.), Currents in Language Teaching. Oxford University Press.

Altbach, P.G. et.al. (1991). Textbooks in American Society: Politics, Policy, and Pedagogy. Buffalo: SUNY Press.

Barry, W. (1977). Piaget's Theory of Cognitive Development, New York \& London: Longman.

Biehler, R.F. (1978). Psychology Applied to Teaching. Boston: Hougton Mifflin Company.

Buckingham, B.R. (1960). "Textbooks", in Encyclopedi of Educational Research, Third Edition, (ed.) Chester W. Harris, (ass.) Marrie R. Liba, The MacMillan Company, New York.

Badan Standar Nasional Pendidikan (BSNP). (2006). Kurikulum dalam Konteks Standar Nasional Pendidikan.

Chambliss, M.J. dan R.C. Calfee, (1998), Textbooks for Learning: Nurturing Children's Minds, Massachusetts: Blackwell Publishers.

Clarke, D. F. (1989). "Communicative Theory and It's Influence on Materials Production". Language Teaching, 22, 73-86.

Covey, S.R., (2006), The 8th Habit: Melampaui Efktivitas, Menggapai Keagungan, Penerjemah Wandi S. Brata dan Zein Isa, Jakarta: Gramedia.

Greene, H. dan W. T. Petty. (1971). Developing Language Skills in the Elementary Schools. Boston: Allyn and Bacon, Inc.

Halliday, M.A.K. (1975). Learning How to Mean: Exploration in the Development of Language. London: Edward Arnold.

Johnson, E. B., (2002). Contextual Teaching and Learning: What is is and why it's here to stay. United states of America: Corwin Press, Inc.
Littlejohn, A., \& S. Windeatt. (1989). "Beyond Language Learning: Perspective on Materials Design". In R. K. Johnson (Ed.), The Second Language Curriculum. Cambridge: Cambridge University Press.

Locked, M. dan A. Verspoor. (1990). Improving Primary Education in Developing Countries: A Review of Policy Options. Washington DC: World Bank.

O’Neill, R. (1990). "Why Use Textbooks?" In R. Rossner and R. Bolitho, (Eds.), Currents in Language Teaching. Oxford University Press.

Patrick, J.J. (1998). High School Government Textbooks. Eric Digest, Ed 301532, December.

Pusat Perbukuan. (2005). Peraturan Menteri Pendidikan Nasional Nomor 11 Tahun 2005 tentang Buku Teks Pelajaran. Jakarta: Departemen Pendidikan Nasional.

Pusat Perbukuan, (2005). Pedoman Penilaian Buku Pelajaran Bahasa dan Sastra Indonesia SD, SMP, dan SMA, Jakarta: Pusat Perbukuan Departemen Pendidikan Nasional.

Rusyana, Y. dan M. Suryaman. (2004). Pedoman Penulisan Buku Pelajaran Bahasa dan Sastra Indonesia SD, SMP, dan SMA. Jakarta: Pusat Perbukuan Departemen Pendidikan Nasional.

Supriadi, D. (2000). Anatomi Buku Sekolah di Indonesia: Problematika Penilaian, Penyebaran, dan Penggunaan Buku Pelajaran, Buku Bacaan, dan Buku Sumber. Yogyakarta: Adicita.

Suryaman, M. (2001). "Model Pembelajaran Membaca Berbasis Bacaan dan Pembaca: Studi tentang Bacaan Narasi dan Eksposisi serta Pembaca Siswa di SLTP”. Disertasi pada PPs UPI.

Suryaman, M. (2004). "Keterbacaan Buku teks pelajaran", Makalah Pelatihan Penulisan Buku Teks Pelajaran di Jogjakarta, Palu, Papua, dan Bengkulu yang diselenggarakan oleh Pusat 
Perbukuan Depdiknas dan Dinas Provinsi Periode 2004.

Suryaman, M. (2005). "Interpretasi Kurikulum dalam Penulisan Buku Pelajaran Bahasa dan Sastra Indonesia" dalam Menuju Budaya Menulis: Suatu Bunga Rampai, (ed. Pangesti Widarti), Yogyakarta: Tiara Wacana.

Suryaman, M. dan Utorodewo, V.N. (2006). Pemilihan dan Pemanfaatan Buku
Pelajaran yang Memenuhi Syarat Kelayakan, Jakarta: Pusat Perbukuan Departemen Pendidikan Nasional.

World Bank, (1995). Indonesia: Book and Reading Development Project, Staff, Appraisal, May.

Yap, K.O. (1978). "Relationship Between Amount of Reading Ability and Reading Achievement". Reading Journal, 17, (1). 